\title{
Analysis of the cycle of domestic violence against women
}

\author{
Kerle Dayana Tavares de Lucena ${ }^{1}$, Layza de Souza Chaves Deininger ${ }^{2}$, \\ Hemílio Fernandes Campos Coelho², Alisson Cleiton Cunha Monteiro ${ }^{3}$, \\ Rodrigo Pinheiro de Toledo Vianna ${ }^{2}$, João Agnaldo do Nascimento ${ }^{2}$
}

DOI: http://dx.doi.org/10.7322/jhgd.119238

\begin{abstract}
Introduction: Violence against Women (VAW) has been produced under the hierarchical organization of male dominance in social relations between genders. It is a type of social relationship that is historically bounded, culturally legitimized and cultivated, in which the woman is exposed to objective and subjective aggression, both in public as well as private sectors. The consequences of the violence suffered by women materialize in biological, psychological and social harms that hamper them fully experiencing human and social equalities. The persistence and the multiplicity of forms of expressing violence against women, throughout history, indicate the importance of the theme and the need to investigate how this practice interferes with the process of living, illness and death of the victim.

Objective: To analyse the cycle of domestic violence against women.

Methods: This is a population-based survey, and cross-sectional, exploratory and descriptive study, using a quantitative approach. The study was conducted in the city of Joao Pessoa-PB, from August 2013 to December 2015. The population consisted of 424 women over 18 years old, and residing in the city of study. For data collection, two instruments were used: the WHO VAW STUDY and the WHOQOL BREF scale, validated for assessing quality of life. A descriptive analysis was performed, from absolute and relative frequencies for the following variables: sociodemographic; Domestic Violence against Women (DVAW) and QOL, in addition to the average for continuous variables; under CAAE number 20418813.0.0000.5183.

Results: The women averaged an overall score of 61.59 for the quality of life index, on a scale from 0 to 100. Regarding scores for each domain, the domain of social relations had the highest average among the domains (69.84), whereas the environment domain had the lowest average (51.03).

Conclusions: Domestic Violence against Women directly and adversely affects the quality of life of the victimized women in numerous aspects, because it interferes with the physical and psychological health of women in society and in their social relations, also bringing consequences for the health system.
\end{abstract}

Key words: women's health, gender identity, domestic violence.

\section{INTRODUCTION}

The term domestic violence against women (DVAW) was adopted by the United Nations (UN) at the General Assembly of 1993. Although many authors use terms like "intimate partner violence" and "family violence against women", the adoption of the term "domestic violence against women” took into account numerous studies, choosing the latter term, because it is the most common among studies from the United States. Since then, its broader definition has been established and violence against women has come to be defined as any act of gender-based violence that produces or may produce harm or physical, sexual or mental suffering of women, including threats of such acts, coercion or arbitrary deprivation of liberty, whether in public or private life.

Violence against Women (VAW) can be explained as a phenomenon constructed from the naturalization of

1 Universidade Estadual de Ciências da Saúde de Alagoas (UNCISAL), Trapiche da Barra, Maceió AL, Campos III. Departamento de Saúde Pública (UNCISAL). Pós-graduação em Modelos de Decisão em Saúde (UFPB).

2 Universidade Federal da Paraíba (UFPB), Castelo Branco III, João Pessoa PB, Campos III. Departamento de estatística (UFPB). Pósgraduação em Modelos de Decisão em Saúde (UFPB).

3 Faculdade de Ciências Médicas da Paraíba. João Pessoa(PB) Brasil

Correspondig author: Kerle Dayana Tavares de Lucena. Email: kerledayana@gmail

Suggested citation: Lucena KDT, Deninger LSC, Coelho HFC, Monteiro ACC, Vianna RPT, Nascimento JA. Analysis of the cycle of domestic violence against women. J Hum Growth Dev. 26(1): 139-146. Doi: http://dx.doi.org/10.7322/jhgd.119238

Manuscript submitted: Feb 23 2016, accepted for publication Mar 192016. 
gender inequality. This is based on hierarchical categories, historically constructed as one of the ideological mechanisms capable of legitimizing the status quo, among which are social classifications and, within these, sexual classification. ${ }^{1}$

VAW has been produced under the hierarchical organization of male domination in social relations between the genders. It is a kind of social relationship that is historically bounded, culturally legitimized and cultivated, in which the woman is exposed to objective and subjective aggression, both in public as well as private spaces. The consequences of violence suffered by women materialize in biological, psychological and social harms that hamper them fully experiencing human and social equalities. The persistence and the multiplicity of forms of expression of violence against women, throughout history, indicate the importance of this issue and the need to investigate how this practice interferes with the process of life, illness and death of its victims.

Gender violence is a broader concept, including victims such as women, children and adolescents of both genders. In the exercise of patriarchal function, men have the power to determine the conduct of these social categories, receiving authorization or at least tolerance from society to punish what is presented as a deviation. Although there is no attempt of the potential victims to tread different paths prescribed by social norms, implementing the domination-exploitation project of the men's social category requires abilities of leadership, aided by violence. Indeed, the gender ideology is insufficient to ensure the compliance of the potential victims to the patriarchs' dictates, which results in the use of violence. ${ }^{2}$

Domestic violence is defined by Schraiber and D’Oliveira $^{3}$ as acts committed by family members, colleagues or former colleagues who live, or not, in the same environment, and can be committed in any place. It predominantly occurs inside the home; however, the abuser often pursues his victim in the workplace, which is still defined as domestic violence.

In this study, the term violence against women in the domestic sphere was used, distinguishing the following elements: a) the use of verbal or physical force that harms or threatens the life and body of the woman physically, emotionally or sexually; b) coercion as a means of perpetuating female subordination; and c) harm inflicted by a partner who establishes or has established an intimate relationship. Based on the current definitions, domestic violence against women was first considered from a gender perspective; in this way, both were used as synonyms, as well as partner violence, because such designations allow us to address more broadly traditional forms of violence, including the violation of women's human rights.

The health services are part of the route taken by most women victims of domestic violence. However, these services often do not assess the aggression, or the act of violence itself, but the injury or damage caused by it. This occurs because the injury is the specific issue of health, particularly in the hegemonic approach of Cartesian care and the exclusively biologicist model. ${ }^{4}$

Thus, even recognized violence is not properly assessed in the health services, which favours its invisibility as a social phenomenon interfering with the health-disease process. In this context, domestic violence against women is a problem of public and collective health and, as such, requires the coordination of health services with other institutions such as the Security Secretariats and Women's Police Stations. It also requires consideration in the educational area, the training of Human Resources, and the adoption of strategies to fight the problem, and, with this study, we hope to contribute to its visibility and understanding. ${ }^{5}$

Regarding the consequences of violence on women's lives and health, Guedes et $\mathrm{al}^{6}$ and Lucena et $\mathrm{al}^{5}$ confirmed in their studies that, in João Pessoa, the violence significantly impacts the physical, mental and social health of the victimized women. Problems such as hypertension, heart disease, anxiety disorders, sleeping and eating disorders, depression, stress, stroke, facial paralysis, and sexual problems were reported by study participants as direct consequences of violence to their health and social life.

Given its complexity, domestic violence remains a challenge for the health sector. Among the difficulties to overcome this challenge are obstacles to diagnosis, such as cultural factors, lack of orientation of users and health professionals, leading to a conclusion that both involved groups of subjects are afraid to deal with the phenomenon. ${ }^{7}$

Under this perspective, the WHO created a tool called "World Organization Violence against Women" (WHO VAW STUDY), which aims to assess domestic violence against women. In this instrument, the higher the score, the greater the diversity of acts of violence suffered by them. In this study, we used the validated instrument to estimate its occurrence, its determinant actors and the association with quality of life along with the World Health Organization Quality of Life-Abbreviated (WHOQOL-Bref) instrument.

This study adopts the concept of quality of life as a citizenship right, and its concept is the foundation of a set of indicators. A concept of QOL is proposed, in which the environmental issue is aggregated to the other items measured by the Human Development Index (HDI). In this design, quality of life is defined as the sum of economic, environmental, scientific, cultural and collective policies established and made available to individuals so that they can accomplish their potential. ${ }^{8}$

Given the above, for all the problems caused by violence against women, this study aimed to analyse the cycle of domestic violence against women.

\section{METHODS}

This is a population-based, cross-sectional, exploratory and descriptive survey, with a quantitative approach. The households were the unit of analysis in the city of João Pessoa-PB. The study was conducted from August 2013 to December 2015.

The population consisted of 424 women over 18 years old, living in the city of study. The following inclusion criteria were used: households in the city of João Pessoa, in which women over 18 years old live. The exclusion 
criteria were: households with deaf-mute women; households with no family structure and households where the women did not have the cognitive ability to answer the questionnaire.

The sample design used for producing the data was determined by the stratified sampling of the neighbourhoods of Joao Pessoa. The target population was defined as all city households, being the list of these households provided by João Pessoa City Hall, considering the year 2014 as a reference. The sample selection was then carried out according to the optimal allocation method concerning the number of households by neighbourhood, and considering the cost of fixed selection for all elements of the target population. The blocks in each district were covered by the research team, including all households with women over 18 years old, who were selected to participate.

Data collection was conducted by interviewers who had received prior training and met the following criteria: to be university students in the health field and to have an availability of at least eight hours a week for collection. The visits were carried out in households selected for research where, after clarification of the research objectives and signature of the informed consent form, the household's responsible answered the survey questions. Data were collected through a semi-structured guide.

For data collection, two instruments were used: 1) WHO VAW STUDY instrument validated to estimate gender violence against women, and 2) WHOQOL BREF instrument validated for assessment of quality of life.

The semi-structured guide collected information about the family characteristics and socio-economic indicators, such as: number of inhabitants, gender, age, marital status, level of education of the members and economic status (source of income), number of workers in each family, family income, per capita income, participation in supplementary income and social support programme; place of residence; housing conditions; access to public sanitation services; accessibility and conditions of health care, education, security and transport; health, social network and social support conditions.

To assess QoL, the WHOQOL-BREF instrument was used. This consists of 26 questions, two about self-assessment of QOL and 24 questions representing each of the WHOQOL-100 facets. For the composition of the WHOQOL-Bref questions, the issue of each facet that had the highest correlation with the average score of all facets was selected. Thus, the WHOQOL-Bref consists of four areas: Physical, Psychological, Social Affairs and the Environmental.

In accordance with the resolution $466 / 12$, of $12^{\text {th }}$ December 2012, of the National Health Council, after explaining the objectives, the women who agreed to participate signed the informed consent form. The research project was submitted to the Research Ethics Committee of the University Hospital Lauro Wanderley and approved under CAAE number 20418813.0.0000.5183, in August 2013.

Initially, data were tabulated in a spreadsheet (Microsoft Office Excel 2008), then, using SPSS for Windows version 18.0 (Statistical Package for the Social Sciences) and later transferred to another statistical package (R software, version 2.14.1).

A descriptive analysis was conducted, from absolute and relative frequencies for the following variables: sociodemographic; DVAW and QOL, in addition to the average for continuous variables. The prevalence of DVAW was also estimated, and the gender violence cycle scheme was presented.

\section{RESULTS} years old.

The average age of the interviewed women was 35

\section{Sociodemographic data of the women}

Table 1: Sample distribution according to marital status, education, race, puppies, income and occupation, João Pessoa, 2015

\begin{tabular}{|c|c|c|}
\hline Variables & $\mathbf{n}$ & $\%$ \\
\hline \multicolumn{3}{|l|}{ Marital status } \\
\hline Married & 150 & $36 \%$ \\
\hline Single & 103 & $24 \%$ \\
\hline Divorced & 86 & $20 \%$ \\
\hline Consensual union & 85 & $20 \%$ \\
\hline Total & 424 & $100 \%$ \\
\hline \multicolumn{3}{|l|}{ Education } \\
\hline Incomplete Elementary School & 108 & $25 \%$ \\
\hline Complete Elementary School & 145 & $34 \%$ \\
\hline Incomplete High School & 50 & $12 \%$ \\
\hline Complete High School & 28 & $7 \%$ \\
\hline Graduated & 93 & $22 \%$ \\
\hline Total & 424 & $100 \%$ \\
\hline \multicolumn{3}{|l|}{ Breed } \\
\hline White & 204 & $48 \%$ \\
\hline Black & 121 & $29 \%$ \\
\hline Yellow & 5 & $1 \%$ \\
\hline Mixed & 94 & $22 \%$ \\
\hline Total & 424 & $100 \%$ \\
\hline \multicolumn{3}{|l|}{ Children } \\
\hline No & 84 & $20 \%$ \\
\hline Yes & 340 & $80 \%$ \\
\hline Total & 424 & $100 \%$ \\
\hline \multicolumn{3}{|l|}{ Employment status } \\
\hline Housekeeper & 298 & $70 \%$ \\
\hline Unemployed & 100 & $24 \%$ \\
\hline Others & 26 & $6 \%$ \\
\hline Total & 424 & $100 \%$ \\
\hline
\end{tabular}

Source: Thesis data, 2015.

Looking at Table 01, in relation to marital status, $55 \%$ of the women lived with a partner. Regarding the educational attainment variable, it is observed that $25 \%$ of the sample women did not complete elementary school and $22 \%$ had completed higher education. In this study, the reported level of violence for women with higher education was almost equal to that of women who had not completed elementary school, revealing the need for 
emancipation from gender oppression.

Regarding the variable of ethnicity/colour, $48 \%$ of women self-reported as white. As this variable is self-reported, there may be masked bias of the data, considering that many women may belong to another ethnic group. Regarding children and employment variables, $80 \%$ of women have children and 70\% have a stable income.

Estimation of prevalence of DVAW and QOL assessment

As the survey was conducted considering the total of city households to calculate the sample and not the total number of women, the found indicator was also related to the number of households. Although the city of João Pessoa has 64 neighbourhoods, some of them were assessed together, such as: Bancários, Mumbaba, among others; as the geographical region was large for the sample size, in order to obtain more information, 55 neighbourhoods were selected. After calculating the prevalence of each neighbourhood, the calculation of the overall estimated prevalence for the city of Joao Pessoa was performed; regarding domestic violence against women in 2015, this estimative was $54.40 \%$ at a $95 \%$ significance level.

Table 2: Descriptive Statistics of WHOQOL-Bref domains. João Pessoa, 2015

\begin{tabular}{|c|c|c|c|c|c|}
\hline DOMAINS & MEDIAN & MEDIAN & STANDARD DEVIATION & MINIMUM & MAXIMUM \\
\hline Physicist & 67,94 & 66,85 & 2,38 & 61 & 74 \\
\hline Psychological & 63,48 & 63 & 2,48 & 53 & 69,3 \\
\hline Social Relationships & 69,84 & 69 & 3,1 & 64 & 76 \\
\hline Environment & 51,03 & 51 & 2,53 & 45 & 56 \\
\hline IQV General & 61,59 & 60,84 & 1,88 & 56 & 67,59 \\
\hline
\end{tabular}

Source: Thesis data, 2015.

It is observed in Table 02 that the participants had the highest score in the social relations field and the lowest one in the environment field.

According to the results shown in Table 2, the general QOL of the women in this study corresponds to 61.59 on a scale from 0 to 100 . As for the scores for each domain, it appears that the field of social relations had the highest average among the domains (69.84), whereas the environment domain had the lowest average (51.03).

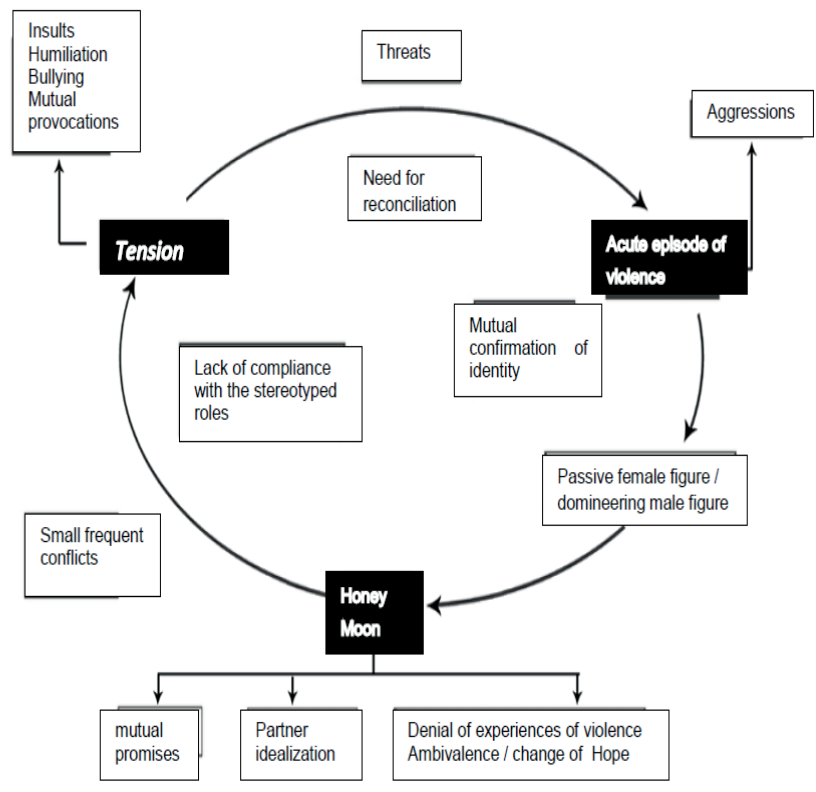

Figure 1: Domestic violence against women cycle.

Figure 1 shows a representation of the cycle of domestic violence against women. According to the testimony of women who have suffered DV, the marital relationship is initially permeated by insults, humiliation, intimidation, mutual provocations, creating conflict and tension. Then, there is a need for confirmation of the deprecation and inferiority of women added by threats of violence until the confirmation of the phenomenon's acute episode. The woman is placed as an object and passive figure, serving only for biological reproduction. On the other hand, the man is regarded as a subject that uses physical force and domination. He appropriates the object woman, denies the experience of DVAW, blaming her for the act of violence. At last, he suggests he will change and the relationship will be transformed from mutual promises of change, but the cycle is renewed after the considered "honeymoon", 
because there is a lack of compliance with the covenants and stereotypical roles, making the DVAW phenomenon recurrent.

\section{DISCUSSION}

The data presented in this study on the estimated prevalence (54\%) of domestic violence against women in Joao Pessoa in 2015 corroborate the data released by WHO and the Pan American Health Organization (PAHO). The data show there is no country or city immune to violence. Interpersonal violence, practised by men against women, is considered one of the biggest global problems today, with values between $10 \%$ and $69 \%$ of incidence, occurring daily in private and domestic spaces. ${ }^{9}$

According to Adeodato ${ }^{10}$, who outlined the profile of women who have suffered DV, 64\% were living with a partner, and in the research of Garcia et $\mathrm{al}^{11}$ this figure was $72.2 \%$. Regarding the variable educational attainment, studies by Lima ${ }^{12}$ showed lower levels of education (34\%). Another survey found that 52.6\% had not completed primary school. ${ }^{11,13}$

In a study by Silva ${ }^{14}$, the variable educational attainment influenced the occurrence of the event, demonstrating that the higher the purchasing power of the women, the lower the tolerance with the aggressor. In the research by Lima ${ }^{12}$, this variable was not statistically significant for the occurrence of DVAW. For Adeodato ${ }^{10}$, DVAW data involving women with higher purchasing power and better education may be underreported by the tendency to hide the phenomenon in that social stratum. However, in this study, the reported level of violence for women with higher education was almost equal to that of women who had not completed elementary school, revealing the need for emancipation of gender oppression.

Regarding the ethnicity/colour variable, since this variable is self-reported, there may be masked bias of the data, considering that many women may belong to another ethnic group. The research conducted by Lima ${ }^{12}$ also indicated that white women constituted the majority of the analysed data.

Concerning children and employment variables, for Alves ${ }^{15}$ and Silva ${ }^{14}$, children can help women to break the cycle of violence and separate from the assailant. Independent women believe that the abuser may change and improve the marital relationship, according to a study by Garcia et $\mathrm{al}^{11}$. This hope leaves these women in a subordinate condition, although they do not financially depend on the abuser, making it difficult to break the silence of victimized women.

The general Quality of Life Index (QLI) of women in this study corresponds to 61.59 in a scale from 0 to 100 . In the study by Lima ${ }^{12}$, the score of women who have suffered gender violence was 42.14. Other studies that generally compare the QoL of men and women revealed that women's QoL is lower than men's. ${ }^{15}$

Monitoring the quality of life of women who have suffered domestic violence means reducing the inequities of that segment that receive unequal social treatment. Therefore, it is necessary to implement public policies that focus on women's health through an intersectoral coordination, in addition to improving mechanisms to curb DVAW, mobilizing various stakeholders regarding the sharing of decisions with instruments that can guarantee constitutional rights to victimized women.

The social relations domain had the highest average among the domains (69.84), corroborating research conducted by Lima ${ }^{12}$, whose respective score was 51.9, and by Castro ${ }^{16}$, with a higher average (77.9). This may be related to the social support offered to women suffering DVAW and the family support available.

The support of the social and family network is recognized by women as fundamental in the process of overcoming the violence perpetrated by an intimate partner. One study shows that $82.2 \%$ of battered women sheltered with family and friends when suffering violence. ${ }^{12}$

The environment domain had the lowest average (51.03), corroborating several studies that evaluated the quality of life of women in general, (38.3 and 55.2). ${ }^{12,17}$ In this area, the women answered questions about physical environment, financial resources, housing, among others, which may be related to the financial dependence of most women, causing submissive relationships.

It can be seen that violence is a reality present in the daily lives of its female victims and this situation affects the health and the quality of their lives. This study revealed a high prevalence of DVAW (54\%). In the pioneering research by Heise et $\mathrm{al}^{18}$, which gathered data from 35 studies in 24 countries, and in the study by Schraiber et $\mathrm{al}^{19}$, the high incidence of violence of men against women was statistically proven, the most endemic form being the sexual and physical violence of intimate partners against their women, which reinforces the phenomenon as a serious public health problem.

Palazzo et $\mathrm{al}^{20}$ claim that $40 \%$ to $70 \%$ of female homicides in the world are committed by intimate partners; in São Paulo, the prevalence was $27 \%$ and, in Pernambuco, 34\%. According to the same study, when it comes to physical violence, it is emphasized that, in the female age group from 20 to 29 years old, there was a higher prevalence of victimization (40.9\%) compared to men (21.1\%).

DVAW is predictable and, therefore, must be faced, not only in the field of philosophy and law, but also in health. From this perspective, the importance of intervening in terms of health is essential, with intersectoral actions, both for the recovery of victims and, more importantly, to prevent further harm.

It is noteworthy that DVAW is more transparent and less acceptable, probably due to the activist movements opposing violence against women. This may explain the higher levels of domestic violence rates in the Brazilian female population. The lower acceptability of violence perpetrated by an intimate partner can trigger a higher sensitivity and greater visibility of domestic violence. Cultural differences regarding the ease of expression can also be factors revealing violence against women. ${ }^{3}$

Although there is progress in combating the phenomenon, women still experience it in their social relations of everyday life, and veiled social and symbolic situations that involve gender issues. Undeniably, these 
situations affect psychological and physical health, as well as women's quality of life. However, the ways in which they give meaning to domestic violence are not yet fully known and understood in a systematic way. This is reflected in the fact that the current difficulties in dealing with the problem of violence and assisting victims are substantial, both for the professionals of basic health services that mention as barriers aspects related to the victims, the lack of knowledge and their own skills to address situations of violence, as much as for the health service structure.

When considering that men and women are responsible for the social reproduction of this androcentric domination, which constitutes a social order of unjust and violent domination, one sees that such a situation is perpetuated despite some achievements and changes obtained by feminism. This human reality has a long history, and it will only be subject to change through policy interventions that can focus on several instances, such as education, church, family and state that contribute to the social reproduction of the dominant order. ${ }^{21}$

The cycle of violence begins in a slow and silent way, which progresses in severity and consequences. The abuser often does not initially use physical attacks, but takes away the individual freedom of the victim and promotes humiliation and embarrassment. Thus, before assaulting her physically, he is importunate in order to lower the self-esteem of the victimized woman, so that later she tolerates the physical abuse. Therefore, psychological violence usually precedes physical violence; however, the first must be identified regardless of its relationship with the second. The woman victim of aggression tends to be accepting, to justify her aggressor's actions and delay the exposure of her troubles until the situation becomes intolerable. ${ }^{5}$

Quality of life is a concept developed by the society from people's experiences, knowledge that have meanings and values that give their stories in a given time and space where they live. Therefore, quality of life is a socially constructed definition and carries a specific cultural identity, which, in turn, reflects a pattern seen by the society as an enabler of satisfaction and well-being.

Meneghel et $\mathrm{al}^{22}$ highlight the fact that episodes of DVAW should not be seen at the institutional level as individual situations and merely subject to approaches with specific treatments focused on physical harm. On the contrary, the authors argue that the issue needs to be considered as an ethical violation of the human rights of women. Nevertheless, one needs to understand the fact as a social phenomenon whose central issue is gender inequalities. Therefore, the focus should be acting on gender inequities, not only offering care to mitigate the consequences and effects at the individual and behavioural level.
It is considered that gender inequality is a central issue of the violence phenomenon and, thus, it is possible to consider that oppression, as a factor that involves unequal power and submission, is also a fundamental core to understanding violence as a social phenomenon that results from gender inequality. Thus, the oppression is a way of exercising the power of the dominant patriarchal value of masculinity and, at the same time, also helps to perpetuate the inequities of power expressed in unequal gender relations.

The study shows that the participants have low quality of life (61.59). The QOL of the women who suffered violence (59.61) is lower than that of women who did not suffer (66.79).

The repetition of DVAW, with its important consequences, leaves lasting scars in women, undermining their autonomy and directly influencing their quality of life, according to data from this study.

Unfortunately, research relating to the two issues discussed is still scarce and little was known about the impact of DVAW on QoL of victimized women. The data obtained in this research, as well as the decision-making models used, can support managers in the decision-making process in the area of women's health concerning the identification of gender violence.

In short, domestic violence against women comes to directly and negatively affect the quality of life of victimized women in many ways, as it interferes with the physical and psychological health of women in society and their social relations, bringing consequences also for the health system. DVAW, subtle or declared, produces marks on the body and soul of those who experience it, negatively impacting on various aspects of her life, particularly on health. Conditions that affect people's health, thus, entail negative effects and damage to quality of life.

Considering the complexity of DVAW, an essentially cultural phenomenon that is only subject to significant change gradually over generations, it is emphasized that any behaviour change involves reflection, questioning various social bodies such as the family, school, work, church, among others. These changes in ways of thinking and acting that may occur over generations over historical time may, indeed, lead to the formation of a new social order.

The State, as the defining instance of public policies, including those related to community health, must articulate professional practices in health with social superstructure and quality of life. In the context of health care, it is necessary to train the professionals in gender issues, which requires institutional and intersectoral accountability of services, as well as theoretical knowledge to support health professionals involved in health care for victims of violence.

\section{REFERENCES}

1. Guedes RN, Silva ATMC, Fonseca RMGS. A violência de gênero e processo saúde-doença das mulheres. Rev Enferm Esc Anna Nery. 2009;13(3):625-31. DOI: http://dx.doi.org/10.1590/S141481452009000300024

2. Kronbauer JFD, Meneghel SN. Perfil da violência e gênero perpetrada por companheiro. Rev Saúde Pública. 2005;39(5):695-701. DOI: http://dx.doi.org/10.1590/S0034-9102005000500001 
3. Schraiber LB, D'Oliveira AFPL. Romper com a violência contra a mulher: como lidar desde a perspectiva do campo da saúde. Athenea Digital. 2008;(14):229-36.

4. Coelho EAC, Silva CTO, Oliveira JF, Almeida MS. Integralidade do cuidado à saúde da mulher: limites da prática profissional. Esc Anna Nery Rev Enferm. 2009;13 (1):154-60. DOI: http://dx.doi.org/10.1590/ S1414-81452009000100021

5. Lucena KDT, Silva ATMC, Freitas WMF, Bezerra IMP, Oliveira AKS, Carício MR. A abordagem de gênero no contexto no trabalho na ESF do município de João Pessoa (PB). Saúde Debate. 2010;34(86):456-66.

6. Guedes RN, Silva ATMC, Coelho EAC, Silva CC, Freitas WMF. A violência conjugal sob o olhar de gênero: dominação e possibilidade de desconstrução do modelo idealizado hegemonicamente de casamento. Online Braz J Nurs. 2007;6(3):5-10.

7. Lobato GR, Moraes CL, Nascimento MC. Desafios da atenção à violência doméstica contra crianças e adolescentes no Programa Saúde da Família em cidade de médio porte do Estado do Rio de Janeiro, Brasil. Cad Saúde Pública. 2012;28(9):1749-58. DOI: http://dx.doi.org/10.1590/S0102-311X2012000900013

8. Fernandes WC, Kimura M. Qualidade de vida relacionada à saúde de mulheres com câncer de colo uterino. Rev Latino-Am Enfermagem. 2010;18(3):65-72.

9. Barreto LC, Prado MAM. Identidade das prostitutas em belo horizonte: as representações, as regras e os espaços. Pesq Práticas Psic. 2011;5(2):193-205.

10. Adeodato GV, Carvalho RR, Siqueira VR, Souza FGM. Qualidade de vida e depressão em mulheres vítimas de seus parceiros. Rev Saúde Pública. 2005;39(1):108-13. DOI: http://dx.doi.org/10.1590/S003489102005000100014

11. Garcia MV, Ribeiro LA, Jorge MT, Pereira GR, Resende AP. Caracterização dos casos de violência contra a mulher atendidos em três serviços na cidade de Uberlândia, Minas Gerais, Brasil. Cad Saude Publica. 2008; 24(11):2551-63. DOI: http://dx.doi.org/10.1590/S0102-311X2008001100010.

12. Lima GQ, Werlang BSG. Mulheres que sofrem violência doméstica: contribuições da psicanálise. Psicol Estud. 2011;16(4):511-20. DOI: http://dx.doi.org/10.1590/S1413-73722011000400002

13. Mota JC, Vasconcelos AGG, Assis SG. Análise de correspondência como estratégia para descrição do perfil da mulher vítima do parceiro atendida em serviço especializado. Ciênc Saúde Coletiva. 2007;12(3):799809. DOI: http://dx.doi.org/10.1590/S1413-81232007000300030

14. Silva MA, Falbo Neto GH, Figueiroa JN, Cabral Filho JE. Violence against women: prevalence and associated factors in patients attending a public healthcare service in the Northeast of Brazil. Cad Saúde Pública. 2010;26(2):264-72. DOI: http://dx.doi.org/10.1590/S0102-311X2010000200006

15. Alves SLB, Diniz NMF. Eu digo não, ela diz sim: a violência conjugal no discurso masculino. Rev Bras Enferm. 2005;58(4):387-92. DOI: http://dx.doi.org/10.1590/S0034-71672005000400002

16. Castro ML, Cunha SS, Souza DPO. Comportamento de violência e fatores associados entre estudantes de Barra do Garças, MT. Rev Saude Publica. 2011;45(6):1054-61. DOI: http://dx.doi.org/10.1590/S003489102011005000072

17. Gomes R. A violência enquanto agravo à saúde de meninas que vivem nas ruas. Cad Saúde Pública. 1994; 10(supl.1):156-67. DOI: http://dx.doi.org/10.1590/S0102-311X1994000500011

18. Heise L. Gender-based abuse: the global epidemic. Cad Saúde Pública. 1994;10(supp 1):135-45. DOI: http://dx.doi.org/10.1590/S0102-311X1994000500009

19. Schraiber LB, d'Oliveira AFPL, França-Junior I, Pinho AA. Violência contra a mulher: estudo em uma unidade de atenção primária à saúde. Rev Saúde Pública. 2002;36(4):470-7. DOI: http://dx.doi.org/10.1590/ S0034-89102002000400013

20. Palazzo LS, Kelling A, Béria JU, Figueiredo ACL, Gigante LP, Raymann B, et al. Violência física e fatores associados: estudo de base populacional no sul do Brasil. Rev Saude Publica. 2008;42(4):622-9. DOI: http://dx.doi.org/10.1590/S0034-89102008000400007

21. Silva SA, Lucena KDT, Deininger LSC, Coelho HFC, Vianna RPT, Anjos UU. Análise da violência doméstica na saúde das mulheres. J Hum Growth Dev 2015;25(2): 182-6. DOI: http://dx.doi.org/10.7322/ jhgd.103009

22. Meneghel SN, Bairros F, Mueller B, Monteiro D, Oliveira LP, Collazio ME. Rotas críticas de mulheres em situação de violência: depoimentos de mulheres e operadores em Porto Alegre, Rio Grande do Sul, Brasil. Cad Saude Publica. 2011; 27(4):743-52. DOI: http://dx.doi.org/10.1590/S0102-311X2011000400013

This article is distributed under the terms of the Creative Commons Attribution 4.0 International License (http://creativecommons.org/licenses/by/4.0/), which permits unrestricted use, distribution, and reproduction in any medium, provided you give appropriate credit to the original author(s) and the source, provide a link to the Creative Commons license, and indicate if changes were made. The Creative Commons Public Domain Dedication waiver (http://creativecommons.org/publicdomain/zero/1.0/) applies to the data made available in this article, unless otherwise stated. 


\section{Resumo}

Introdução: A VCM tem-se produzido sob a organização hierárquica do domínio masculino nas relações sociais entre os sexos. É um tipo de relação social historicamente delimitada, culturalmente legitimada e cultivada, na qual a mulher está exposta a agressões objetivas e subjetivas, tanto no espaço público como no privado. As consequências da violência sofrida pela mulher materializamse em agravos biológicos, psicológicos e sociais que dificultam sua experiência de viver a igualdade humana e social plenamente. A persistência e a multiplicidade das formas de expressão da violência contra a mulher, ao longo da história, indicam a importância do tema e a necessidade de se investigar como essa prática interfere no processo de viver, adoecer e morrer de quem as sofre.

Objetivo: analisar o ciclo da violência doméstica contra a mulher.

Método: Trata-se de um Inquérito de base populacional, transversal, exploratório, descritivo de abordagem quantitativa. O estudo foi desenvolvido no município de João Pessoa-PB no período de agosto de 2013 a dezembro de 2015. A população foi composta por 427 mulheres acima de 18 anos residentes no município cenário do estudo. Para a coleta de dados, foram utilizados dois instrumentos: WHO VAW STUDY e WHOQOL BREF validado para avaliação da qualidade de vida. Realizou-se uma análise descritiva, a partir de frequências absolutas e relativas para as variáveis: sociodemográficas; VDCM e QV, além da média para as variáveis contínuas. Sob CAAE de $n^{\circ}$ 20418813.0.0000.5183. Resultados: em relação ao índice de qualidade de vida geral das mulheres deste estudo corresponde a 61,59 numa escala de 0 a 100. Quanto aos escores de cada domínio, verifica-se que o domínio das relações sociais foi o que obteve melhor média dentre os demais domínios $(69,84)$, e o domínio meio ambiente com a menor média $(51,03)$.

Conclusões: a violência doméstica contra a mulher vem afetar direta e negativamente a qualidade de vida das mulheres vitimizadas em diversos aspectos, pois interfere na saúde física e psicológica da mulher, na sociedade e suas relações sociais, trazendo consequências, também, para o sistema de saúde.

Palavras-chave: saúde da mulher, identidade de gênero, violência doméstica. 